\title{
IMPLEMENTASI PASAL 82 UU NO. 7 TAHUN. 1989 JIS UU NO. 3 TAHUN. 2006 JIS UU NO. 50 TAHUN 2009 PADA PERKARA PERCERAIAN (STUDI KASUS PADA PENGADILAN AGAMA KLAS 1. A PALU)
}

\author{
Ahmad Mirwan ${ }^{1}$, Muhammad Akbar ${ }^{2}$, Suhri Hanafi ${ }^{3}$ \\ ${ }^{1}$ Student Faculty of Shariah IAIN Palu, email: ahmadmirwan12@gmail.com \\ ${ }^{2}$ Lecturer Faculty of Shariah IAIN Palu, email: \\ muhammadakbar2870@gmail.com \\ ${ }^{3}$ Lecturer Faculty of Shariah IAIN Palu, email: atriabyan@gmail.com
}

\begin{abstract}
This study aims to provide knowledge and understanding of the implementation of article 82 of Law no. 7 of 1989 JIS Law No. 3 of 2006 Law no. 50 of 2009 in divorce cases in Class I A Palu Religious Court, and how the efforts and solutions of Class I A Palu Religious Court in dealing with divorce. This research was designed using a type of field research, using a qualitative approach. After analyzing the research data, the final step of this research is checking the validity of the data with a view to proving that the research is truly valid. Results obtained from research in the Religious Courts concerning Implementation of article 82 of Law, no. 7 years. 1989 JIS Act. No. 3 years 2006 Law No. 50 years. 2009 concerning divorce cases is mandatory because it is a necessity to run it and has been implemented well as evidenced by existing data. The solution in dealing with divorce cases is to mediate and make trainings for judges to better understand the various cases in divorce.
\end{abstract}

Keywords: Divorce, Article, Religious Court Class I.A, Case

\begin{abstract}
Abstrak: Penelitian ini bertujuan untuk memberikan pengetahuan dan pemahaman terhadap pengimplementasian pasal 82 UU No. 7 tahun 1989 JIS UU No. 3 tahun 2006 UU no. 50 tahun 2009 pada perkara perceraian di Pengadilan Agama Klas I A Palu, dan bagaimana upaya dan solusi Pengadilan Agama Klas I A Palu dalam mengatasi perceraian. Penelitian ini di desain dengan menggunakan jenis penelitian lapangan, dengan menggunakan pendekatan kualitatif. Setelah menganalisis data penelitian tersebut maka langkah terakhir penelitian ini adalah pengecekan keabsahan data dengan maksud untuk membuktikan penelitian tersebut benar-benar absah keberadaannya. Hasil yang diperoleh dari penelitian di Pengadilan Agama tentang Implementasi pasal 82 UU, no. 7 tahun. 1989 JIS UU. No. 3 thm. 2006 UU No. 50 tahun. 2009 tentang perkara perceraian adalah wajib dilakukan karena sebuah keharusan menjalankannya dan telah terimplementasi dengan baik yang dibuktikan dengan data yang ada. Adapun solusi dalam mengatasi perkara perceraian adalah melakukan mediasi dan membuat pelatihanpelatihan untuk para hakim agar dapat lebih memahami berbagai perkara dalam perceraian.
\end{abstract}

Kata kunci: Perceraian, Pasal, Pengadilan Agama Klas I.A, Perkara 


\section{A. Pendahuluan}

Hukum di Indonesia merupakan campuran dari sistem Hukum Eropa, Hukum Agama dan Hukum Adat. Sebagian besar sistem yang dianut, baik perdata maupun pidana, berbasis pada hukum Eropa Kontinental, khususnya dari Belanda karena aspek sejarah masa lalu Indonesia yang merupakan wilayah jajahan dengan sebutan Hindia Belanda. ${ }^{1}$

Hukum Agama, karena sebagian besar masyarakat Indonesia menganut Agama Islam, maka dominasi hukum atau Syari'at Islam lebih baik banyak terutama di bidang perkawinan, yang merupakan penerus dari aturan-aturan setempat dari masyarakat budaya-budaya yang ada di Wilayah Nusantara.

Penegasan undang-undang Peradilan Agama, Undang-Undang Nomor 7 Tahun 1989, yang mengatur tentang susunan, kekuasaan, dan hukum acara Peradilan Agama, sesuai penjelasannya di dalam pembukaan dan penjelasan umum, adalah bertujuan untuk mengakhiri pengaturan susunan, kekuasaan, dan hukum acara yang selama ini masih beraneka ragam, demi terciptanya kesatuan hukum yang mengatur peradilan agama.

Pemberlakuan hukum acara perdata secara universal baik di lingkungan peradilan umum maupun di lingkungan Peradilan Agama sebenarnya masih menyisakan persoalan. Di satu sisi, Peradilan Agama merupakan salah satu lingkungan peradilan yang melaksanakan kekuasaan kehakiman di Indonesia yang derajat dan kedudukannya sama dengan lingkungan peradilan yang lain. Akan tetapi, di sisi lain Peradilan Agama merupakan Peradilan Khusus yang menangani perkara-perkara tertentu bagi pencari keadilan yang beragama Islam salah satunya yaitu masalah perkara perceraian.

Persoalan mengenai cerai sebagai upaya mengabsahkan talak dan legalitasnya. Hukum Acara di pengadilan Agama, yang dimunculkan di dalam Kompilasi Hukum Islam, sementara sebelumnya hanya dikenal dua jenis perkara perceraian, yaitu permohonan cerai talak dari suami dan gugat cerai dari istri.

${ }^{1}$ Abdul Djamali, Pengantar Hukum Indonesia, (Ed.II, cet. VII, Jakarta: Raja Grafindo Persada, 2001), 314. 
Dalam suatu gugatan selalu ada pihak penggugat dan pihak tergugat, terkadang juga melibatkan pihak turut tergugat. ${ }^{2}$

Dari penjelasan di atas dapat diungkapkan bahwa dalam sebuah sidang harus dilaksanakan proses atau usaha-usaha dalam mendamaikan perkara perceraian, namun banyak pula yang terjadi masyarakat yang hendak melaksanakan perkara perceraian tidak faham akan proses-prosesnya hal inilah yang menjadi fokus penulis untuk di teliti pada Pengadilan Agama Klas I Palu. Dengan demikian, untuk memecahkan masalah tersebut tulisan ini berusaha menjawab pertanyaan berikut ini:

Bagaimana Implementasi pasal 82 UU. No. 7 Tahun. 1989 JIS UU. No. 3 Tahun. 2006 JIS UU. No. 50 Tahun. 2009 tetang perkara perceraian pada Pengadilan Agama Kelas I A Palu? Dan Apa upaya dan solusi yang dilakukan Pengadilan Agama Palu dalam mengatasi perkara perceraian?

Untuk itu, tulisan ini bertujuan untuk menjelaskan bagaimana implementasi pasal 82 UU. No. 7 Tahun. 1989 JIS UU. No. 3 Tahun. 2006 JIS UU. No. 50 Tahun. 2009 tetang perkara perceraian pada Pengadilan Agama Kelas I A Palu. Dan Apa upaya dan solusi yang dilakukan Pengadilan Agama Palu dalam mengatasi perkara perceraian.

Penelitian ini merupakan kategori penelitian lapangan (field research), dan penelitian ini menggunakan pendekatan kualitatif. Adapun tujuan pemilihan penelitian dengan menggunkan pendekatan kualitatif adalahmendeskrpsikan berupa kata-kata tertulis atau lisan dari orang-orang yang dapat di amati di lapangan.

\section{B. Tinjauan Tentang Peradilan Agama}

1. Pengertian Peradilan Agama

Peradilan agama adalah sebutan resmi bagi salah satu di antara empat lingkungan Peradilan Negara atau Kekuasaan Kehakiman yang sah di Indonesia. ${ }^{3}$

\footnotetext{
${ }^{2}$ Abdul Manan, Penerapan Hukum Acara Perdata di Lingkungan Peradilan Agama dalam Aris Bintania Hukum Acara peradilan Agama, (cet. II, Jakarta; Rajawali Pers, 2013), 4.

${ }^{3}$ UU No. 14 tahun1970, LN 1970-74 tentang Ketentuan-ketentuan Pokok Kekuasaan Kehakiman, Pasal 10 ayat (1). Kata-kata "Peradilan Negara" dan "Kekuasaan Kehakiman" adalah semakna.
} 
Dalam hal ini, Peradilan Agama hanya berwenang di bidang perdata tertentu saja, tidak pidana dan pula tidak hanya untuk orang-orang Islam di Indonesia, dalam perkara-perkara perdata Islam tertentu, tidak mencakup seluruh perdata Islam. Peradilan Agama ialah proses pemberian keadilan berdasarkan hukum Islam kepada orang-orang Islam yang dilakukan di Pengadilan Agama dan Pengadilan Tinggi Agama. Pengadilan Agama merupakan salah satu pelaksanan kekuasaan Kehakiman dalam negara Republik Indonesia selain Peradilan Umum, Pengadilan Tata Usaha Negara, Pengadilan Militer dan Mahkamah Konstitusi. ${ }^{4}$

2. Kekuasaan Peradilan Agama

Berbicara tentang kekuasaan peradilan dalam kaitannya dengan Hukum Acara Perdata, biasanya menyangkut dua hal, yaitu :

a. Kekuasaan relatif

Kekuasaan relatif diartikan sebagai kekuaasan pengadilan yang satu jenis dan satu tingkatan, dalam perbedaannya dengan kekuasaan pengadilan yang sama jenis dan sama tingkatan lainnya, misalnya antara Pengadilan Negeri Magelang dengan Pengadila Negeri Purworejo, antara Pengadilan Agama Muara Enim dengan Pengadilan Agama Baturaja.

Pengadilan Negeri Magelang dan Pengadilan Negeri Purworejo satu jenis, sama-sama lingkungan Peradilan Umum dan sama-sama Pengadilan tingkat pertama. Pengadilan Agama Muara Enim dan Pengadilan Agama Baturaja satu jenis, yaitu sama-sama lingkungan Peradilan Agama dan satu tingkatan, samasama tingkat pertama.

Pada penjelasan pasal 4 ayat (1) berbunyi: "Pada dasarnya tempat kedudukan pengadilan agama ada di kotamadya atau di ibu kota kabupaten, yang daerah hukumnya meliputi wilayah kotamadya atau kabupaten, tetapi tidak tertutup kemungkinan adanya pengecualian".

b. Kekuasaan absolut

Kekuasaan absolut artinya kekuasaan pengadilan yang berhubungan dengan jenis perkara yang ditangani. Tentang kekuasaan Absolut ini diatur dalam Undang-undang Nomor 3 tahun 2006 perubahan atas Undang-undang Nomor 7

${ }^{4}$ Ibid. 
Tahun 1989, pasal 2 disebutkan "Peradilan Agama adalah salah satu pelaku kekuasaan kehakiman bagi rakyat pencari keadilan yang beragama Islam mengenai perkara tertentu sebagaimana dimaksud dalam undang-undang ini". 5

Selanjutnya pada pasal 49 disebutkan Pengadilan Agama bertugas dan berwenang memeriksa, memutus, dan menyelesaikan perkara-perkara di tingkat pertama antara orang-orang yang beragama Islam di bidang:

a) Perkawinan;

b) Kewarisan, wasiat, dan hibah, yang dilakukan berdasarkan hukum Islam;

c) Wakaf dan shadaqah.

Inilah yang menjadi wewenang absolut Peradilan Agama dalam menjalankan tugasnya sebagai sala satu Pelaksanaan Kehakiman.

c. Susunan Badan Peradilan Agama

Berdasarkan Pasal 9 ayat (1) Undang-Undang Nomor 3 Tahun 2006 tentang Perubahan atas Undang-Undang Nomor 7 Tahun 1989 tentang Peradilan Agama, susunan Pengadilan Agama terdiri dari, Pimipinan, Hakim Anggota, Panitera, Sekertaris dan Juru Sita.

Sedangkan susunan Pengadilan Tinggi Agama sebagaimana penjelasan Undang-undang Nomor 3 Tahun 2003 perubahan atas Undang-undang Nomor 7 Tahun 1989, pasal 9 ayat 2 disebutkan susunan Pengadilan Tinggi Agama terdiri dari: Pimipinan, Hakim anggota, Panitera, dan Sekertaris. ${ }^{6}$

d. Tahapan-tahapan pemeriksaan perkara

Pemeriksaan perkara di tingkat pertama dilakukan melalui tahap-tahap pemeriksaan perkara yang dimulai dari:

1) Pembukaan sidang

Pada sidang pertama yang ditetapkan melalui penetapan hari sidang, meskipun para pihak sudah dipanggil ada kemungkinan pihak tidak hadir dalam persidangan, ketidakhadiran pihak menentukan keadaan pemeriksaan yang dilakukan.

${ }^{5}$ Republik Indonesia, Undang-Undang RI Nomor 3 Tahun 2003 tentang Perubahan atas Undang-Undang Nomor 7 Tahun 1989.

${ }^{6}$ Ibid. 
2) Penanyaan identitas para pihak

Setelah sidang dinyatakan dibuka untuk menghindari eror in personal (keliru mengenai orang) maka hal pertama yang dilakukan oleh majelis hakim adalah menanyakan identiitas pihak-pihak, dimulai dati penggugat dan selanjutnya tergugat meliputi nama, bin/ti, alias/ julukan/ gelar, umur, agama, pekerjaan, dan tempat tinggal terakhir. Penanyaan identitas bersifat formal, meskipun majelis hakim sudah pengenal pihak-pihak tetap haru dilakukan penanyaan identitas bersifat kebijaksanaan umum dalam persidangan yang dilakukan oleh Ketua Majelis yang bertanggung jawab mengenai arah pemeriksaan. Selain itu majelis juga menanyakan apakah para pihak ada/tidak memilki hubungan darah dengan para hakim dan panitera yang menyidangkan perkara, untuk mengantisipasi adanya kewajiban hakim mengundurkan diri dalam pemeriksaan perkara, atau justru ada pihak yang mennyatakan menolak hakim mengadili perkara karena alasan tersebut.

3) Anjuran damai

Pada sidang pertama jika kedua belah pihak hadir maka pengadilan berusahan mendamaikan mereka, jika berhasil perkara diakhiri dengan perdamaian yang dituangkan dalam Akta Perdamaian yang kekuatan hukumnya sama dengan putusan, tetapi tidak hanya dapt dibuat dalam perkara mengenai sengketa kebendaan saja yang memungkinkan untuk dieksekusi.

4) Pembacaan gugatan

Setelah gugatan dibacakan, sebelum tahap jawaban tergugat berkesempatan untuk menyatakan sikap sehubungan dengan gugatannya.

5) Jawaban tergugat

Jawaban tergugat dapat diberikan secara tertulis atau lisan yang harus dihadiri oleh tergugat atau kuasa hukumnya meskipun ada mengirimkan surat jawaban tertulis, maka jawaban itu tidak akan diperhatikan dan dianggap tidak pernah ada, kecuali jika jawaban itu berisi eksepsi bahwa pengadilan tersebut tidak berwenang mengadili. Eksepsi adalah tangkisan/ sanggahan terhadap gugatan yang bukan mengenai pokok perkara, untuk menghindari gugatan dengan meminta hakim menetapkan gugatan tidak diterima. 


\section{6) Replik Penggugat}

Setelah tergugat memberikan jawabannya, selanjutka kesempatan beralih kepada penggugat untuk memberikan replik yang menanggapi jawaban tergugat sesuai dengan pendapatnya. Penggugat mungkin mempertahankan gugatan dan menambah keterangan untuk memperjelas dalil-dalilnya atau malah mengubah sikap dengan membenarkan jawabannya/ bantahan tergugat.

7) Duplik Tergugat

Setelah replik penggugat maka bagi penggugat dapat membalasnya dengan mengajukan duplik yangg memungkinkan sikapnya sama seperti replik penggugat. Replik dan duplik (jawab-menjawab) dapat terus diulangi sampai didapat titik temu atau dianggap cukup oleh hakim.

8) Pembuktian

Pada dasarnya setelahh acara replik dan duplik berakhir, Majelis Hakim sudah dapat mempertimbangkan apakah gugatan dapat diterima untuk diberi putusan akhir, yaitu gugatan dapat diterima untuk diberi putusan akhir, yaitu ketika seluruh dalil-dalil gugatan sudah jelas, diakui atau tidak disangkal lawan. Tetapi, jika dalil-dalil gugat masih belum jelas maka diperlakukan pembuktian, Ketua Majelis akan menentukan pihak yang harus menghadiri bukti melalui putusan sela.

Pembuktian merupakan rangkaian tindakan hakim dalam melaksanakan tugas pokok pemeriksaan perkara, yaitu mengonstatir perkara, hakim harus pasti akan kebenaran peristiwa yang dikonstatirnya sehingga hasil nya bukan sekedar dugaan atau kesimpulan yang dangkal dan gegabah. Hakim harus menggunakan sarana atau alat-alat untuk memastikan dirunya tentang kebenaran peristiwa yang bersangkutan.

9) Kesimpulan para pihak

Setelah tahap pembuktian berakhir sebelum dibacakan keputusan, pihak diberikan kesempatan untuk memberikan pendapat akhir yang merupakan kesimpulan mereka terhadap hasilpemeriksaan selama persidangan. Kesimpulan sifatnya membantu Majelis Hakim, pihak yang sudah biasa berperkara biasanya selalu membuat catatan-catatan penting mengenai persidangan dan catatan itulah 
biasanya yang diajukan sebagai kesimpulan, mengingat hakim adalah juga manusia biasa yang kemampuan ingatannya juga terbatas, di samping mungkin ada pergantian Majelis Hakim dalam persidangan. Dalam perkara-perkara yang sederhana dan jika memang tidak diperlukan kesimpulan para pihak dapat ditiadakan.

10) Musyawarah Majelis Hakim

Terhadap hasil pemeriksaan yang sudah dilakukan selanjutnya majelis hakim akan melakukan sidang tertutup untuk melakukan perundingan dalam merumuskan putusan melalui musyawarah majelis hakim. Musyawarah Majelis Hakim dilaksanakan secara rahasia dan tertutup untuk umum. Tujuan diadakannya musyawarah adalah untuk menyamakan persepsi agar perkara yang diadili dapat dijatuhkan putusanyang seadil-adilnya sesuai ketentuan hukum yang berlaku. Ketua Majelis memimpin musyawarah dengan memberi kesempatan kepada hakim anggota mengemukakan pendapatnya, setiap hakim mempunyai hak yang sama dalam mengkonstatir, mengualifisir, dan mengkonstituir perkara. Majelis Hakim, kerena jabatannya, harus menambah dasar-dasar hukum yang tidak dikemukakan para pihak, Majelis wajib memberi keputusan semua bagian gugatan dan dilarang memutuskan tentang hal-hal yang tidak dimohonkan, hasil musyawarah hanya dapat diketahui pada saat dibacakan dalam sidang terbuka.

11) Pembacaan Putusan Hakim

Pembacaan putusan dilakukan oleh Ketua Majelis, jika putusannya terlalu panjang dapat dilakukan secara bergantian antara anggota majelis, bagian duduknya perkara dibacakan oleh hakim anggota junior dan tentang hukumnya dibacakan oleh hakim anggota senior, sedangkan amar putusan dibacakan kembali oleh Ketua Majelis. Untuk menghindari terjadinya perbedaan antara bunyi putusan yang diucapkan dengan yang tertulis, putusan baru boleh diucapkan minimal konsep jadi putusan telah disiapkan dengan sebaik-baiknya dan telah diparaf oleh semua anggota majelis. 


\section{Pembahasan}

1. Implementasi Pasal 82 UU. No. 7 Thn. 1989 JIS UU. No. 3 Thn. 2006 JIS UU. No. 50 Tahun 2009 Tentang Perkara Perceraian pada Pengadilan Agama Klas I A Palu

Dalam pasal 82 UU. No. 7 Tahun 1989 JIS UU. No. 3 Tahun 2006 JIS UU. No. 50 tahun 2009 tentang perkara perceraian pada pengadilan klas Pengadilan Agama dapat dikatakan wajib pengimplementasiannya karena sudah masuk dalam rana undang-undang dan wajib untuk dilaksanakan oleh setiap pengadilan yang ada di Indonesia, seperti yang diutarakan oleh Ahmad P selaku Hakim di Pengadilan Agama Palu:

Pengimplemensian undang-undang ini wajib, karena memang telah tercantum dalam undang-undang, dan kami sebagai petugas pengadilan wajib mengimplementasikannya.

a. Proses penyelesaian perkara

Adapun proses dalam penyelesaian perkara perceraian di Pengadilan Agama Palu dapat dilakukan dengan beberapa tahapan-tahapan. Tahapan pertama melakukan pendaftaran, dan pihak pengadilan akan memanggil tergugat yang akan telah mendaftarkan gugagatan perceraiannya, tahapan selanjutnya yaitu tahapan persidangan yakni pada pemeriksaan sidang pertama, hakim berusaha mendamaikan kedua belah pihak, dan suami istri harus datang secara pribadi. Apabila hakim tidak berhasil, maka hakim mewajibkan kepada kedua belah pihak agar lebih dahulu menempuh mediasi.

Mediasi dapat dilakukan oleh hakim sendiri, atau hakim dapat menunjuk hakim yang lain untuk melakukan mediasi pada orang yang melakukan gugatan perceraian, atau penggugat dapat menunjuk langsung siapa yang akan melakukan mediasi kepadanya. Mediasi ini dilakukan agar tercapainya perdamaian antara kedua belah pihak yang melakukan perkara sehingga tidak perlu melakukan perpisahan dalam hal ini disebut juga dengan perceraian. Namun proses pelaksanakan perkara perceraian dalam pengimplementasian pasal 82 UU No. 7

${ }^{7}$ Ahmad P., Hakim/Humas Pengadilan Agama Klas I A Kota Palu, "wawancara" oleh penulis di Kantor Pengadilan Agama klas I A Kota Palu, tanggal 27 September 2016 
tahun 1982 JIS UU No. 3 tahun 2006 JIS UU No. 50 tahun 2009 ini mengalami beberapa hambatan yang akhirnya menimbulkan akibat yang sedikit menghambat dari penerapan pasal tersebut berikut penuturan Ahmad P selaku Hakim Pengadilan Agama Klas I Palu:

Beberapa dari pelaku perkara dalam hal ini tergugat tidak meluangkan waktu untuk menghadiri persidangan sehingga menghambat jalannya persidangan sendiri, banyaknya orang-orang yang tak mengerti akan hukum, dan anggaran khusus yang disediakan oleh pemerintah yang mengharuskan tim mediator menggunakan dana sendiri untuk menghubungi jika yang berpekara berada di luar kota, serta orang-orang yang mengetahui tentang hukum masih mempertanyakan sertifikasi hakim, seedangkan masih banyak hakim-hakim yang belum tersertifikasi sehingga banyak yang menolak kasusnya di tangani. ${ }^{8}$

Dari penuturan Pak Ahmad P dapat disimpulkan bahwa melakukan implementasi pasal tersebut dapat terlaksana jika adanya dukungan dari orangorang yang berperkara yang setidaknya dapat meluangkan waktunya untuk memenuhi panggilan dari pihak pengadilan serta dukungan dari pemerintah untuk memberikan dana khusus kepada pengadilan agar tim mediator dapat menghubungi orang-orang yang berperkara tanpa adanya kendala dana.

b. Akibat atau dampak tidak terimplementasinya pasal 82 No.7 tahun 1989

Dari wawancara dengan berbagai narasumber, penulis juga menanyakan akibat ataupun dampak yang terjadi jika tidak terimplementasinya pasal tersebut sesuai dengan penuturan Herlina selaku penggugat:

Dalam melakukan proses perkara perceraian gampang-gampang susah, karena ada bebaerapa hal yang dipersulit seperti harus mendatangi pengadilan secara pribadi tanpa harus di wakili dan penundaan karena tidak datangnya salah satu yang dari yang berperkara untuk mediasi, jadi menghambat proses bagi pasangan-pasangan yang ingin pisah atau bercerai seperti saya. ${ }^{9}$

Dari penuturan Herlina bisa dilihat betapa susahnya pengimplementasian pasal yang dimaksud karena kurangnya yang mengakibatkan lambatnya proses untuk melakukan mediasi, banyak yang menginginkan perceraian secepatnya tanpa harus adanya mediasi, yang menurut beberapa orang tidak perlu dilakukan

${ }^{8}$ Ibid

${ }^{9}$ Herlina Pelaku perkara “wawancara” Tanggal 27 Agustus 2016 
karena keputusan yang dipilih (penggugat) untuk berpisah sudah tidak bisa ditawar dan media pendamai tidak di haruskan.

Adapun menurut Pak Ahmad P mengenai upaya perdamaian di persidangan dalam hal ini disebut mediasimerupakan asas hukum acara Peradilan Agama yang menjadi kewajiban hakim untuk mengupayakan dalam setiap kesempatan pemeriksaan. Upaya mendamaikan menjadi sebuah kewajiban hukum bagi hakim yang bersifat imperatif terutama dalam sengketa yang ditempuh oleh hakim harus merupakan usaha yang nyata dan optimal, bahkan jika tidak berhasil pada sidang pertama dapat terus diupayakan selama perkara belum diputus dan dalam proses tersebut hakim dapat meminta bantuan kepada orang lain yang ditunjuk seperti mediator bahkan hakin dapat menjadi mediator antara pasangan yang melakukan perkara perceraian.

Berbeda dengan kasus perceraian dengan alasan perselisihan dan pertengkaran, jika alasan diajukan penggugat seperti alasan zina, cacat badan atau jiwa yang berakibat tidak dapat melaksanakan kewajibban atau perkara lainnya di luar perceraian, upaya mendamaikan atau mediasi bukanlah merupakan kewajiban hukum, tetapi fungsinya merupakan kewajiban moral. Adapun upaya mediasi ini dilakukan dalam persidangan dan menjadi kewajiban hukum bagi hakim kerena untuk melihat kemampuan hakim dalam mencegah perceraian yang kasusnya banyak terjadi di Sulawesi Tengah pada umumnya dan di Kota Palu pada khususnya. Berikut penuturan pak Ahmad mengenai upaya perdamaian dalam perkara perceraian:

Jika melihat putusan perkara perceraian atas alasan perselisihan dan sebuah pertenngkaran yang belum atau tidak memenuhi usaha mendamaikan yang dilakukan secara optimal dapat dibatalkan demi hukum, karena bisa di anggap belum memenuhi tata tertib beracara dan untuk itu pengadilan banding atau kasasi harus memerintahkan pemeriksaan ulang melalui putusan sela untuk mengupayakan perdamaian secara optimal. Dari sinilah daplqat dilihat kemampuan hakim untuk menjadi penengah yang adil dan juga dapat di jadikan poin untuk menilai peringkat hakim, semakin banyak kasus yang berakhir secara damai, maka semakin besar jasa hakim yang menangani kasus perkara perceraian. ${ }^{10}$

${ }^{10}$ Ahmad P., Hakim/Humas Pengadilan Agama Klas I A Kota Palu, “ wawancara” oleh penulis di Kantor Pengadilan Agama klas I A Kota Palu, tanggal 27 September 2016 
Hasil akhir perdamaian harus benar-benar hasil kesepakatan melalui kehendak bebas kedua belah pihak, sebab perdamaian dipandang dari sudut Kitab Undang-Undang Hukum Perdata (KUHP/BW) termasuk bidang hukum perjanjian yang menuntut terpenuhinya syarat-syarat seperti yang diatur dalam pasal 1320 dan 1321 KUH perdata. Yakni pertama adanya kesepakatan berdasarkan kehendak bebas kedua pihak. Kedua kesepakatan itu tidak boleh mengandung kekhilafan paksaan baik fisik maupun psikis ataupun Ketiga adanya kecakapan bertindak hukum. Keempat didasarkan atas sebab halal Hakim dalam melaksanakan fungsi mendamaikan harus senantiasa memerhatikan beberapa aspek sehingga tidak terjadi bentuk perdamaian yang dihasilkan merupakan kehendak sepihak dari pihak yang kuat.

Adapun putusan Peraturan Mahkama Agung (PERMA) No. 1 tahun 2016 mengenai mediasi, mendukung sepenuhnya pengadilan agama untuk melakukan proses atau upaya pendamaian pada orang yang melakukan perkara perceraian hal ini sesuai dengan penuturan pak Ahmad P yang mengatakan:

Ada Peratutan Mahkamah Agung yang mendukung tentang proses mediasi yakni PERMA no. 1 tahun 2016, kiranya ada pihak yang berperkara menolak uuntuk mendamaikan, kami memiliki landasan untuk tetap melakukan mediasi seoptimal mungkin pada orang yang melakukan perkara.

Dalam melaksanakan mediasi ini pihak yang berperkara wajib penghadiri secara pribadi tanpa adanya perantara, terkecuali jika ada yang memberikan surat kuasa istimewa yakni pengacara yang ditunjuk langsung oleh pihak yang berperkara dan memiliki hak kuasa istimewa.

c. Perkara yang terdapat pada Pengadilan Agama Palu

Dalam perkara yang ada di Pengadilan Agama klas I A terdapat perkara yang diterima, dicabut, dan diputus menurut jenis perkara pada Pengadilan Agama klas I A Kota Palu, dan berikut laporan grafik perkara perceraian di Pengadilan Agama Kota Palu selama tahun 2013-2015: 


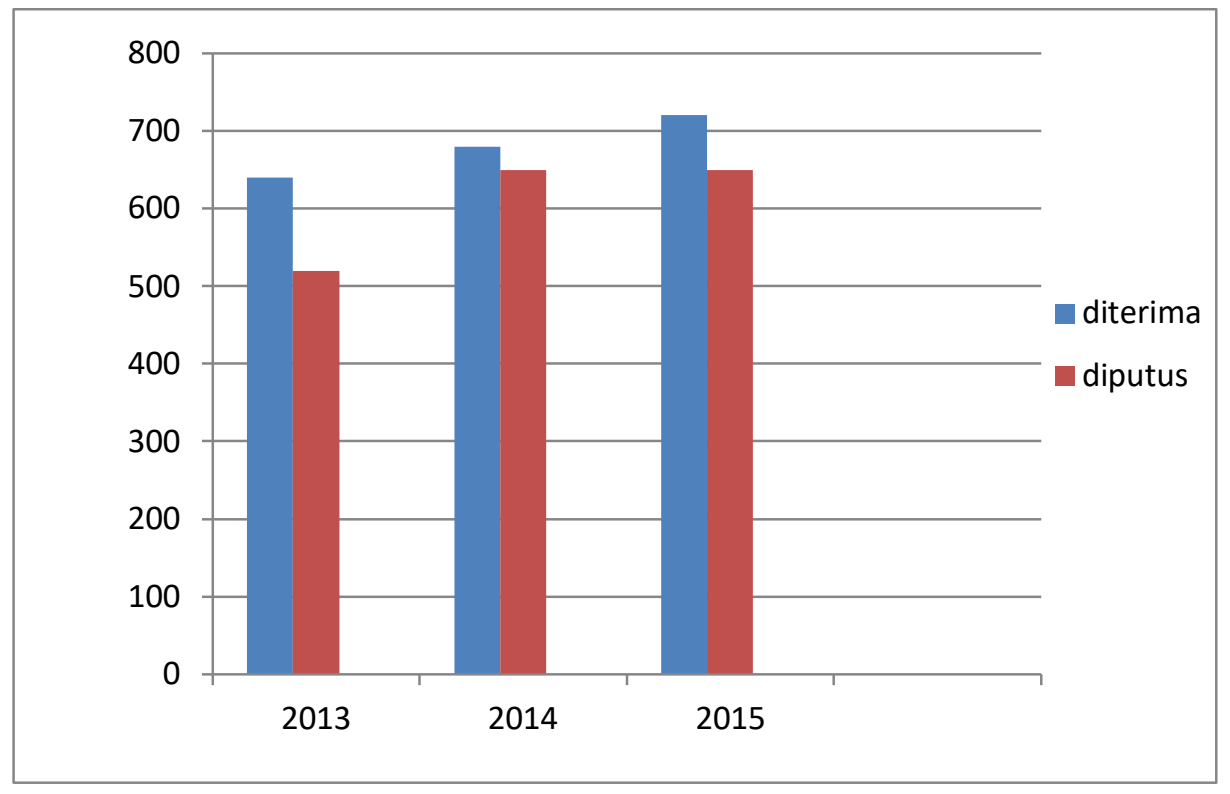

Dari grafik diatas dapat disunpulkan bahwa perkara perceraian yang diterima dan diputus pada Pengadilan Agama klas I A kota Palu terus meningkat setiap tahunnya. Dari data grafik dapat menentukan prestasi hakim dimana jika putusan dicabut secara damai maka dari kedua belah pihak maka hakim dinyatakan berhasil dalam perkaranya. Adapun dalam memproses satu perkara kurang lebih 2 bulan, yang dimulai dari beberapa tahapan yang bisa memakan waktu berminggu-minggu.

\section{Upaya dan Solusi yang Dilakukan Pengadilan Agama Palu dalam Mengatasi Perkara Perceraian}

Dalam mengatasi beberapa kasus perkara perceraian pemerintah telah mengatur dalam berbagai pasal, adapun solusi yang dilakukan oleh pengadilan telah diatur dalam berbagai produk peraturan perundang-undangan, diantaranya di dalam pasal 56 ayat (2) 65, 70, 82, 83, penjelasan ayat (4) pasal 82 UU No. 7 tahun 1989 tentang peradilan Agama, pasal 39 UU No. 1 tahun 1974 tentang perkawinan, pasal 31-32, penjelasan pasal 16 dan ayat (2) pasal 31, PP No. 9 Tahun 1975 tentang aturan pelaksanaan Undang-undang perkawinan, dan Pasal 115, 143, 144 Inpres No. 1 Tahun 1991 tentang Kompilasi Hukum Islam.

Dari keseluruhan redaksi pasal-pasal diatas yang berkaitan dengan upaya pendamaian memmang tidak ditemukan satupun kata yang bermakna dengan 
kewajiban atau keharusan bagi hakim untuk mengupayakan perdamaian antara suami istri secara lebih jauh dan optimal. Akan tetapi, jika melihat rumusan kalimat-kalimatnya jelas penekanannya menunjukan usaha mendamaikan harus lebih jauh dan dengan upaya-upaya yang lebih nyata dan optimal, tidak hanya sekedar memenuhi tuntutan formalitas saja, diantaranya dapat dilihat dari pernyataan-pernyataan sebagai berikut.

Hakim berusaha mendamaikan kedua belah pihak -Pasal 31 PP No. 9/1975; Pasal 82 UUPA--, harus ada cukup alasan bahwa suami istri tidak akan dapat hidup rukun lagi sebagai suami istri -Pasal 39 (2) UU Perkawinan; Pasal 131 (2) KHI--, untuk terjadinya perceraian pengadilan harus memuat alasanalasan dan dasar-dasarnya memuat pasal-pasal tertentu atau sumber hukum tak tertulis sebagai dasar mengadili -62 UUPA - " Selama perkara belum diputus usaha mendamaikan dapat dilakukan pada setiap sidang pemeriksaan -Pasal 31 (2) PP No. 9/1975; Pasal 31 (2) PP. No. 9/ 1974; Pasal 143 (2) KHI-, usaha mendamaikan tidak hanya dapat dilakukan disetiap bidang pemeriksaan bahkan juga dapat dilakukan disemua tingkat peradilan, bahkan dalam mendamaikan pengadilan dapat meminta bantuan kepada orang atau badan hukum lain yang dianggap perlu - penjelasan pasal 82 (4) UUPA; penjelasan pasal 31 (2) PP No. 9/1975--, bila tercapai perdamaian tidak dapat diajukan perceraian baru berdasarkan alasan sebelumnya -Pasal 32 PP No. $9 / 1975$, pasal 83 UUPA; pasal 144 KHI--, dalam sidang perdamaian suami istri harus datang secara pribadi -Pasal 82 (2)UUPA-

Pernyataan-pernyataan di atas semuanya menyiratkan tuntutan untuk mengoptimalkan usaha mendamaikan perkara perceraian sampai usaha-usaha itu dirasakan benar-benar sudah tidak mungkin membuahkan hasil, sehingga alasanalasan untuk dijadikan dasar dalam memutuskan perceraian barulah dianggap mencukupi.

Apabila upaya damai berhasil, maka perkara dicabut tanpa dibuat akta perdamaian karena perjanjian berupa tindak-tanduk, sikap dan tindakan dalam rumah tangga jika dilanggar tidak mungkin dieksekusi dan akibat dari pelanggaran itu tidak menyebabkan putusnya perkawinan. Dikemudian hari jika mereka kembali mengiginnkan perceraian, dimungkinkan mengajuka perkara baru dengan alasan baru bukan dengan alasan sebelumnya yang sudah tercapai perdamaiannya. Apabila perkara perceraian sampai ditingkatkan banding atau kasasi upaya damai masih bisa diusahakan yang jika tercapai, maka perkara dicabut disertaipenetapan oleh pengadilan banding atau kasasi yang membatalkan 
putusan pengadilan tingkat pertama yang mengabulkan perceraian karena terjadi perdamaian sebelum putusan berkekuatan hukum tetap.

Hal itu terjadi pada seluruh untuk pengadilan yang ada di Indonesia begitu pula yang Pengadilan Agama klas I Kota Palu lakukan, megupayakan mediasi seoptimal mungkin agar yang berperkara mencapai putusan perdamaiannya dan tidak ada putusan perpisahan antara suami istri adapun pendapat pak Ahmai $\mathrm{P}$ mengenai upaya dan solusi agar pasangan suami istri mengurungkan niatnya dalam melakukan perkara perceraian:

Banyak cara untuk mengatasi perkara perceraian jika pasangan yang berperkara masih saling mengerti satu sama lain, salah satunya adalah menasehati pasangan serta mengingatkan apa saja yang akan terjadii jika perpisahan tetap menjadi pilihan akhir. Jika memiliki anak hakim akan mengingatkan akibat yang akan terjadi pada anak hasil dari pernikahan mereka. Wajib bagi hakim untuk mencegah perceraian untuk mengurangi angka percereaian yang ada di Indonesia.

Melakukan pelatihan-pelatihan hakim juga dilakukan untuk para hakim agar lebih terbiasa melakukan perkara-perkara yang mengharuskan hakim untuk mengambil keputusan bahkan menjadi mediator jika menagani kasus perkara perceraian, dan juga melatih kecakapan hakim-hakim yang masih baru. Hal ini sesuai penuturan pak Ahmad P:

Salah satu upaya yang kami lakukan adalah melakukan atau membuat pelatihan-pelatihan terhadap para hakim guna melatih kecakapan hakim dalam mengambil keputusan dalam sebuah perkara dan juga mampu menjadi penengah (mediator) jika kasus yang ditangani adalah perceraian.

Dari hal tersebut dapat disimpulkan bahwa salah satu upaya dan solusi Pengadilan Agama dalam kasus perkara pengadilan di kota Palu adalah memberikan nasihat kepada orang yang melakukan perkara perceraian serta memberikan pelatihan-pelatihan kepada hakim.

\section{Penutup}

Dari uraian di atas, maka dapat diambil kesimpulan bahwa Pengadilan Agama Klas 1 Palu dalam mengimplemantasi pasal 82 UU Nomor 7 tahun 1989 JIS UU Nomor 3 tahun 2006 JIS UU Nomor 50 tahun 2009 menjalankan tugasnya senantiasa berpedoman kepada Undang-undang, dan Pengadilan Agama klas 1 A Palu senantiasa telah dijalankan. Adapun dalam penerapannya banyak 
terdapat hambatan-hambatan yang mengakibatkan tidak maksimalnya proses mediasi seperti yang diatur oleh pasal 82 UU Nomor 7 tahun 1989. Antara lain:

1. Kurangnya masyarakat yang sadar akan hukum

2. Kurangnya dukungan pemerintah dalam penyediaan dana

3. Hakim-hakim yang belum tersertifikasi

Adapun tahap atau upaya mendamaikan, pengadilan Agam klas I A Kota Palu memberikan beberapa pelatihan kepada para hakim agar cakap dalam memberikan penilaian terhadap kasus perkara yang ditangani, melaksanakan mediasi dan menjadi mediator langsung juga merupakan hal yang dapat dilakukan dilakukan untuk upaya dan solusi yang dilakukan Pengadilan Agama klas I A Kota Palu dalam kasus perkara perceraian.

\section{DAFTAR PUSTAKA}

Abdul Djamali, Pengantar Hukum Indonesia, Ed.II, Cet. 7, Jakarta: Raja Grafindo Persada, 2001.

Abdul Manan Penerapan Hukum Acara Perdata di Lingkungan Peradilan Agama dalam Aris Bintania Hukum Acara peradilan Agama, Cet, 2, Jakarta; Rajawali Pers, 2013.

Abdul Rahman Ghozaly, Fiqh Munakahat, Cet.3, Jakarta: Kencana, 2013.

Abdurrahman Fhatoni, Metodologi Penelitian dan Teknik Penyusunan Skripsi, Jakarta: PT. Asdi Mahasatya, 2006.

Ahmad Mujahidin, Peradilan Satu Atap di Indonesia, Bandung: IKAPI, 2007. 
Amir Syarifuddin, Hukum Perkawinan Islam di Indonesia, (Jakarta: Kencana, 2007

Depag RI, Al-Quran dan Terjemahnya

Departemen Pendidikan dan Kebudayaan, Kamus Besar Bahasa Indonesia, Cet.I, Jakarta; Balai Pustaka, 1988.

Diana kusumari SH,http//www.hukumonline.com/klinik/detail/c1988/istilah, di akses hari kamis tanggal 28 Jul. 16, pukul 10:12 WITA

H.M.A. Tihami, dan Sohari Sahrani, Fikih Munakahat (Kajian Fikih Nikah Lengkap), Jakarta: PT RajaGrafindo Persada, 2009.

Jaenal Arifin, Peradilan Agama dalam Bingkai Reformasi Hukum di Indonesia, Jakarta: Kencana, 2008.

Joko P. Subagyo, Metode Penelitian Dalam dan Praktek, Jakarta: Rimeka Cipta, 1997.

Kamal Mukhtar, Asas-Asas Hukum Islam Tentang Perkawinan, Jakarta: Bulan Bintang, 1974.

Lexy J Moleong, Metologi Penelitian Kualitatif, Bandung: Remaja Rosda Karya.

Matthew B. Miles dan A. Michael Huberman, diterjemahkan olej Tjejep Rohandi Rosidi, Kualita-tive Data Analysis (Analisis Data Kulaitatif, Buku Tentang Metode-Metode Baru), Cet. I; Jakarta: UI-Press, 1992.

Muhammad bin Isma'il As-Shan'ani, Subulus Salam al-Juz Tsalist, Bairut: Dar alFikr 1991.

Mukti Arto, Praktek Perkara Perdata pada Peradilan Agama, Yogyakarta: Pustaka Pelajar, 1998.

Noeng Muhajir, Metodologi kualitatif, ed.III, Yogyakarta:Reke serasia, 1998.

Oyo Sunaryo Mukhlas, Perkembangan Peradilan Islam...

Undang-Undang No. 7 Tahun 1989 tentang Peradilan Agama.

Republik Indonesia, Undang-Undang RI Nomor 3 Tahun 2003 tentang Perubahan atas Undang-Undang Nomor 7 Tahun 1989.

Siti Soetami, Pengantar Tata Hukum Indonesia, Bandung: Refika Aditama, 2007.

Soemiyati, Hukum Perkawinan Islam dan Undang-Undang Perkawinan (UndangUndang Nomor 1 Tahun 1974 tentang Perkawinan), Yogyakarta: Liberty, 1982.

Soemiyato, Hukum Perkawainan Islam dan Undang-Undang Perkawinan.

Suryadi Suryabrata, Metodologi Penelitian, Jakarta: Raja Grafindo Persada, 1998. 
Tim Penyusun Kamus Pusat Pembinaan dan Pengembangan Bahasa, Kamus Besar Bahasa Indonesia, Edisi Kedua, Jakarta: Balai Pustaka, 2006. 